\title{
Sensibilização ambiental: um diagnóstico na bacia hidrográfica do Rio Belém, Curitiba-PR, a partir da percepção de alunos do ensino fundamental
}

\author{
Luciana Luciane Blum VESTENA
}

Dissertação de Mestrado: Curso de Mestrado em Geografia - UFPR

Data da defesa: 29 set. 2003

Banca:

Ana Maria Muratori (orientadora)

Sony Cortese Caneparo

Daniela Biondi Batista

\section{RESUMO}

O presente estudo teve como objetivo principal avaliar o nível de sensibilização ambiental de alunos do ensino fundamental, especificamente das $3^{\underline{a}}$ e $4^{\underline{a}}$ séries, de escolas públicas e privadas, situadas na bacia hidrográfica do rio Belém, o qual atravessa uma área intensamente urbanizada do município de Curitiba, no estado do Paraná, apresentando um elevado grau de degradação ambiental. A partir dessa avaliação fez-se uma análise sobre o nível de conhecimento e da percepção desses alunos quanto às condições ambientais do rio Belém, considerando-se as metodologias empregadas pelos professores na prática da Educação Ambiental neste nível de ensino. As escolas escolhidas localizam-se nas proximidades do curso superior do Rio Belém, abrangendo um universo de 156 alunos das $3^{\text {a }}$ e $4^{\text {a }}$ séries e 25 professores destes, e envolveram o Colégio Marista Santa Maria, da rede particular de ensino, a Escola Estadual São Francisco de Assis e o Colégio Estadual Ernani Vidal, da rede pública estadual, além da Escola Municipal Mirazinha Braga da rede pública municipal de ensino. A metodologia utilizada pautou-se na abordagem qualitativa de LÜDKE e ANDRÉ (1986), com análise dos conteúdos dos dados de acordo com BARDIn (1977) e PIAGET (1977; 1978). A coleta dos dados deu-se por meio da aplicação de questionários com questões abertas e um mapa mental aos alunos e a realização de entrevista com professores das $3^{\underline{a}}$ e $4^{\underline{a}}$ séries pesquisadas. Os resultados obtidos mostram que grande número de alunos das $3^{\underline{a}}$ e $4^{\text {a }}$ séries apresenta pouca sensibilização ambiental, apesar de a grande maioria conhecer o rio Belém, embora alguns desconheçam o seu nome. As metodologias empregadas pelos professores na prática da Educação Ambiental não estão alcançando seus objetivos propostos. Os meios de atualização em Educação Ambiental e os recursos didáticos utilizados pelos professores são os mesmos - a televisão, revistas e jornais.

Palavras-chave:

Sensibilidade ambiental, educação ambiental, percepção. 